\title{
Chemotaxis, random mobility, and mobilization of polymorphonuclear leucocytes in malnutrition ${ }^{1,2}$
}

\author{
R. K. CHANDRA ${ }^{3}$, S. CHANDRA, AND O. P. GHAI \\ From the Department of Paediatrics, All-India Institute of Medical Sciences, New Delhi 16, India
}

SYNOPSIS Neutrophil mobilization following administration of Pseudomonas polysaccharide was significantly reduced in malnutrition, especially during infection. The random mobility of polymorphonuclear leucocytes (PMNs) was slightly decreased in undernutrition. Chemotactic migration of PMNs was depressed and correlated more with the presence of infection than with nutritional deficiency. It is possible that these abnormalities of PMN mobilization and mobility in malnourished individuals contribute to suboptimal amount, kinetics, and pattern of tissue inflammatory response to bacteraemic challenge.

The common association of malnutrition and infection is well known. In the last few years, immunological studies of undernourished individuals have revealed impaired host defence mechanisms (Chandra, 1974a, 1976a, 1976b). The defects involve serum immunoglobulin levels and antibody response to some antigens (Chandra, 1976c), cell-mediated immunity (Geefhuysen et al, 1971; Smythe et al, 1971; Chandra, 1972; McFarlane and Hamid, 1973), thymus-dependent $T$ lymphocytes in the peripheral blood (Chandra, 1974b; Ferguson et al, 1974), oxidative metabolism and bactericidal capacity of polymorphonuclear leucocytes (PMNs) (Selvaraj and Bhat, 1972; Seth and Chandra, 1972), complement (Sirisinha et al, 1973; Chandra, 1975a), serum siderophilin (Antia et al, 1968), and secretory antibody response (Chandra, 1975c). Similar abnormalities have been noticed in low-birth weight infants who are small for gestational age as a result of fetal malnutrition (Chandra, 1975b, 1974c; Ferguson et al, 1974).

We have studied another parameter of PMN function, namely, neutrophil mobilization, random and chemotactic mobility, and correlated it with nutritional status and the presence of infection.

\footnotetext{
'Supported partly by a grant from the World Health Organization, Geneva

2Presented in part at the Kroc Foundation Workshop on Host Defenses in Malnutrition, Santa Ynez, California, 19-22 May 1975

${ }^{3}$ Present address: Professor of Pediatric Research, Memorial University of Newfoundland, St. John's, Newfoundland, Canada A1C 5S7

Received for publication 28 August 1975
}

\section{Material and Methods}

\section{PATIENTS AND CONTROLS}

Four groups of children in the age group 1-4 years were studied. Group I consisted of $\mathbf{1 0}$ malnourished patients with infection, group II, eight malnourished children without concurrent infection, group III, 10 well nourished children with infection, and group IV, 10 healthy controls. Protein-calorie undernutrition was diagnosed on the basis of history of reduced dietary intake, clinical features such as growth failure, loss of subcutaneous tissues, and hair changes, and anthropometry. Body weight and height were between 50 and $70 \%$ of the 50 th percentile for age on Harvard growth standards. None of the children showed oedema. Infection was documented on clinical and microbiological evidence. The diagnoses included bacterial diarrhoea and dysentery, pneumonia (6 cases each), meningitis ( 2 cases) otitis media ( 2 cases), abscess in the abdominal wall ( 2 cases), and extensive pyoderma and infected scabies (one case each). Enteropathogenic Escherichia coli, Klebsiella, and Staphylococcus aureus were isolated in three instances each, Streptococcus haemolyticus, Salmonella typhi, and Pseudomonas pyocyanea in two instances each, and Streptococcus faecalis and Diplococcus pneumoniae once each. In a few cases, the qualitative nitroblue tetrazolium test (Feigin $e$ $a l, 1971)$ supported the presence of bacterial infection.

The data were analysed by Student's $t$ test of statistical significance.

LEUCOCYTE TESTS

Random mobility was measured by the method 
described by Bryant et al (1966). Cell suspensions containing $5 \times 10^{6} \mathrm{PMNs}$ per $\mathrm{ml}$ of $10 \%$ pooled normal human serum were placed in vertically positioned microhaematocrit tubes. Cell movement from the point of origin to the advancing front of migrating cells was measured after 4 hours with an ocular micrometer.

Chemotaxis was evaluated by Miller and Nilsson's (1970) method. A suspension containing $5 \times 10^{6}$ PMNs per ml was placed on one side of a $3 \mu$ pore membrane filter (Millipore Corporation). Chemotactic factor generated from fresh serum by incubation with $E$. coli was placed on the other side of the filter. After incubation at $37^{\circ} \mathrm{C}$ for 3 hours, the average nurnber of PMNs per high-power field reaching the lowest surface of the membrane was determined.

Mobilization of PMNs from the bone marrow was assessed by two methods: (1) by giving $0.15 \mathrm{ml}$ of 1:1000 aqueous adrenaline solution intravenously and counting the number of neutrophils in the blood just before and at 2, 5, 10, and 20 minutes after administration; (2) by an intravenous injection of $0.05 \mu \mathrm{g}$ per $\mathrm{kg}$ of body weight of Piromen (Pseudomonas polysaccharide) and determining the absolute neutrophil count in the blood at one-hour intervals for 6 hours.

\section{Results}

\section{NEUTROPHIL NUMBER}

The distribution of cases by peripheral blood neutrophil count is given in table I. One child each in groups I, II, and III had significant neutropenia; in two, the diagnosis was typhoid fever, confirmed by microbiological isolation of the organism. A marked increase in total leucocyte count and neutrophils > 6000 per $\mathrm{mm}^{3}$ was observed in five of $10 \mathrm{mal}-$ nourished infected patients and in seven of 10 well nourished children with infection.

\section{NEUTROPHIL MOBILIZATION}

Adrenaline stimulation produced similar increases in absolute neutrophil count in all the groups (table II). Piromen caused a rise in body temperature in all children. There was a marked increase in the neutrophil count of peripheral blood in healthy children (table II); malnourished patients with infection showed a poor response, and groups II and III had intermediate values.

PMN RANDOM MOBILITY

Spontaneous random migration was reduced slightly in malnourished children without concurrent infection (table III). The presence of infection did not

\begin{tabular}{llll}
\hline Group & Number & Neutrophils per mm \\
\cline { 3 - 4 } & & $<2000$ & 2000 to 6000 \\
\hline I Malnourished and infected & 10 & 1 & 4 \\
II Malnourished, no infection & 8 & 1 & 6 \\
III Well nourished, with infection & 10 & 1 & 2 \\
IV Healthy & 10 & 0 & 9 \\
\hline
\end{tabular}

Table I Leucocyte counts

\begin{tabular}{|c|c|c|c|c|c|c|c|}
\hline \multirow{2}{*}{\multicolumn{2}{|c|}{ Group }} & \multicolumn{2}{|c|}{$\begin{array}{l}\text { Mean Increase in Neutrophils } \\
\left(\text { per } \mathrm{mm}^{3}\right) \text { after }\end{array}$} & \multicolumn{4}{|c|}{ Statistical Significance $(\mathbf{P})^{1}$ of Difference from } \\
\hline & & Adrenaline & Piromen $^{1}$ & Group I & Group II & Group III & Group IV \\
\hline $\begin{array}{l}\text { I } \\
\text { II } \\
\text { IIV }\end{array}$ & $\begin{array}{l}\text { Malnourished and infected } \\
\text { Malnourished, no infection } \\
\text { Well nourished, with infection } \\
\text { Healthy }\end{array}$ & $\begin{array}{l}2183 \\
2565 \\
2098 \\
2750\end{array}$ & $\begin{array}{l}1075 \\
2117 \\
2630 \\
6853\end{array}$ & $\begin{array}{l}- \\
<0.05 \\
<0.01 \\
<0.001\end{array}$ & $\begin{array}{l}<0.05 \\
- \\
\text { NS } \\
<0.01\end{array}$ & $\begin{array}{l}<0.01 \\
\text { NS } \\
<0.01\end{array}$ & $\begin{array}{l}<0.001 \\
<0.01 \\
<0.01 \\
-\end{array}$ \\
\hline
\end{tabular}

Table II Maximum increase in absolute neutrophil count following adrenaline or Piromen

${ }^{1} P$ values for data on Piromen only

NS = not significant

\begin{tabular}{|c|c|c|c|c|c|c|c|}
\hline \multicolumn{2}{|c|}{ Group } & \multicolumn{2}{|c|}{ Random Mobility ( $\mathrm{mm})$} & \multicolumn{4}{|c|}{ Statistical Significance (P) of Difference from } \\
\hline & & Range & Mean & Group I & Group II & Group III & Group IV \\
\hline $\begin{array}{r}\text { I } \\
\text { II } \\
\text { III } \\
\text { IV }\end{array}$ & $\begin{array}{l}\text { Malnourished and infected } \\
\text { Malnourished, no infection } \\
\text { Well nourished, with infection } \\
\text { Healthy }\end{array}$ & $\begin{array}{r}8-13 \\
9-14 \\
12-20 \\
15-22\end{array}$ & $\begin{array}{l}10 \\
11 \\
17 \\
18\end{array}$ & $\begin{array}{l}\text { NS } \\
<0.05 \\
<0.05\end{array}$ & $\begin{array}{l}\text { NS } \\
<0.05 \\
<0.05\end{array}$ & $\begin{array}{l}<0.05 \\
<0.05 \\
-\end{array}$ & $\begin{array}{l}<0.05 \\
<0.05 \\
\text { NS } \\
\end{array}$ \\
\hline
\end{tabular}

Table III Random mobility of polymorphonuclear leucocytes

NS $=$ not significant 
make any appreciable difference in this function.

\section{PMN CHEMOTAXIS}

Directed non-random migration was profoundly depressed in malnourished children with infection (table IV). Infection was the apparent determining factor for this abnormality since the well nourished infected group also showed a significant reduction of PMN chemotaxis.

\section{Discussion}

Our observations indicate that mobilization and movement of PMNs may be significantly impaired in malnutrition, especially in the presence of infection. The data provide an explanation for the type and intensity of inflammatory response mounted by an undernourished individual challenged by a pathogen.

The poor neutrophil response of malnourished children with Pseudomonas polysaccharide indicates impaired marrow release. In severe kwashiorkor, concurrent infection may elicit little or no leucocytosis (Trowell et al, 1954). Asirvadham (1948) induced turpentine abscesses in protein-deficient rats and found no leucocytic response. The bone marrow was atrophic. The abnormalities were reversed on refeeding. A slowing down of cell generation and tissue proliferation is a basic alteration of the organism in response to protein deficiency. Bone marrow with its rapid cell turnover is no exception (Sood et al, 1965). In protein-deficient rabbits, intravenous administration of Staph. aureus elicited a poor and transitory neutrophil response, the bacteria persisted and multiplied in the blood and tissues, the lesions were necrotic rather than localized abscesses, and there was an early high mortality (Bhuyan and Ramalingaswami, 1972).

Additionally, endotoxaemia associated with infection may deplete the marrow PMN reserves. Endotoxin is frequently detected in the blood of malnourished children (R. Suskind, personal communication).

Neutrophil response following adrenaline administration was comparable in all the four groups studied. The slight differences in the mean absolute increase in PMNs of malnourished and healthy children were not statistically significant. Thus, no change in the non-marrow or marginal pool of neutrophils was demonstrable.

There are two basic types of movement shown by PMNs-random, unstimulated mobility, and nonrandom migration directed to a chemotactic stimulus. In malnourished children, random mobility was slightly reduced; the differences were statistically significant at the $5 \%$ level of probability. It is possible that this defect is due to changes induced by protein-calorie deprivation in the cell membrane, the amount of contractile actin in the microfilaments or in its polymerization ability. Chemotaxis was reduced maximally in malnourished patients with concurrent infection. It is possible that both infection and undernutrition contribute to this impairment, though the role of the former was obviously much more significant since well nourished children with infection (group III) also showed a marked reduction in chemotactic migration (table IV). Data from another group are in conformity with our observations on chemotaxis (Rosen et al, 1975). The kinetics of the chemotactic response are significantly altered in kwashiorkor (Steven Douglas, personal communication). Preliminary data obtained by E. R. Stiehm (personal communication) indicate that the generation of chemotactic factor(s) from the serum of healthy and malnourished subjects is comparable.

It is possible that in malnourished individuals abnormalities of PMN mobilization and mobility described above contribute to the suboptimal quantity, kinetics, and pattern of tissue inflammatory response to bacteraemic challenge.

\section{References}

Antia, A. U., McFarlane, H., and Soothill, J. F. (1968). Serum siderophilin in kwashiorkor. Arch. Dis. Child., 43, 459-462.

Asirvadham, M. (1948). The bone marrow and its leukocytic response in protein deficiency. $J$. infect. Dis., 63, 87-100.

Bhuyan, U. N. and Ramalingaswami, V. (1972). Responses $N$ of the protein-deficient rabbit to staphylococcal bacteremia. $\sigma$ Amer. J. Path., 69, 359-368.

Bryant, R. E., Desprez, R. M., Vanway, M. H., and Rogers, D. E. (1966). Studies on human leukocyte motility. I. $\omega$

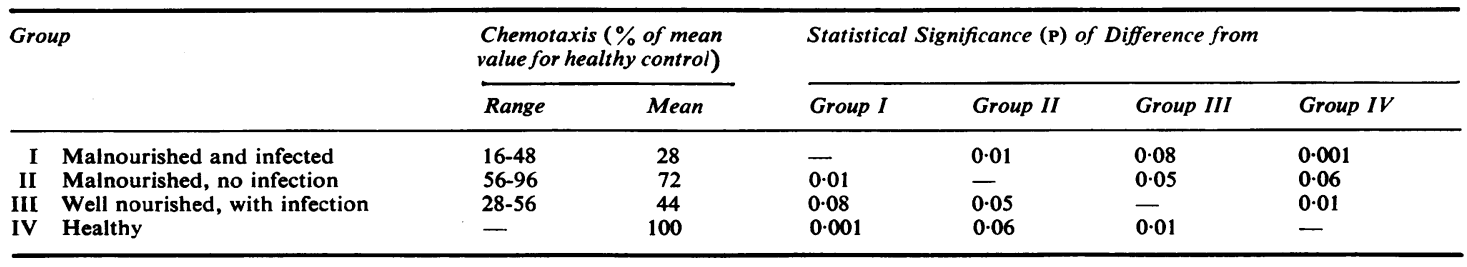

Table IV Response of polymorphonuclear leucocytes to chemotactic stimulus 
Effects of alterations in $\mathrm{pH}$, electrolyte concentration, and phagocytosis on leukocyte migration, adhesiveness, and aggregation. J. exp. Med., 124, 483-499.

Chandra, R. K. (1972). Immunocompetence in undernutrition. J. Pediat., 81, 1194-1200.

Chandra, R. K. (1974a). Interactions of infection and nutrition. In Progress in Immunology II, Vol. 4, by $\mathrm{L}$. Brent and J. Holborow, p. 355. North Holland, Amsterdam.

Chandra, R. K. (1974b). Rosette-forming T lymphocytes and cell-mediated immunity in malnutrition. Brit. med. J., 3, 608-609.

Chandra, R. K. (1974c). Immunocompetence in low-birthweight infants after intrauterine malnutrition. (Letter). Lancet, 2, 1393-1394.

Chandra, R. K. (1975a). Serum complement and immunoconglutinin in malnutrition. Arch. Dis. Childh., 50, 225-229.

Chandra, R. K. (1975b). Fetal malnutrition and postnatal immunocompetence. Amer. J. Dis. Child., 129, 450-455.

Chandra, R. K. (1975c). Reduced secretory antibody response to live attenuated measles and poliovirus vaccines in malnourished children. Brit. med. J., 2, 583-585.

Chandra, R. K. (1976a). Nutrition as a critical determinant of susceptibility to infection. Wld Rev. Nutr. Diet. (In press).

Chandra, R. K. (1976b). Immunological consequences of malnutrition including fetal growth retardation. In Food and Immunology. Symposium XIII of the Swedish Nutrition Foundation. Almqvist and Wiksell International, Stockholm.

Chandra, R. K. (1976c). Immunoglobulins and antibody formation in malnutrition. In Host Defenses in Malnutrition, edited by R. Suskind. Raven Press, New York.

Feigin, R. D., Shackelford, P. G., Choi, S. C., Flake, K. K., Franklin, F. A., Jr., and Eisenberg, C. S. (1971). Nitroblue tetrazolium dye test as an aid in the differential diagnosis of febrile disorders. J. Pediat., 78, 230-237.

Ferguson, A. C., Lawlor, G. J., Jr., Neumann, C. G., Oh,
W., and Stiehm, E. R. (1974). Decreased rosette-forming lymphocytes in malnutrition and intrauterine growth retardation. J. Pediat., 85, 717-723.

Geefhuysen, J., Rosen, E. U., Katz, J., Ipp, T., and Metz, J. (1971). Impaired cellular immunity in kwashiorkor with improvement after therapy. Brit. med.J., 4, 527-529.

McFarlane, H., and Hamid, J. (1973). Cell-mediated immune response in malnutrition. Clin. exp. Immunol., 13, 153-164.

Miller, M. E., and Nilsson, U. R. (1970). A familial deficiency of the phagocytosis-enhancing activity of serum related to a dysfunction of the fifth component of complement (C5). New Engl. J. Med., 282, 354-358.

Rosen, E. U., Geefhuysen, J., Anderson, R., Joffe, M., and Rabson, A. R. (1975). Leucocyte function in children with kwashiorkor. Arch. Dis. Childh., 50, 220-224.

Selvaraj, R. J., and Bhat, K. S. (1972). Metabolic and bactericidal activities of leukocytes in protein-calorie malnutrition. Amer. J. clin. Nutr., 25, 166-174.

Seth, V., and Chandra, R. K. (1972). Opsonic activity, phagocytosis, and bactericidal capacity of polymorphs in undernutrition. Arch. Dis. Childh., 47, 282-284.

Sirisinha, S., Suskind, R., Edelman, R., Charapatana, C., and Olson, R. E. (1973). Complement and C3-proactivator levels in children with protein-calorie malnutrition and effect of dietary treatment. Lancet, 1, 1016-1020.

Smythe, P. M., Schonland, M., Brereton-Stiles, G. G., Coovadia, C. C., Grace, H. J., Loening, W. E. K., Mafoyane, A., Parent, M. A., and Vos, G. H. (1971). Thymolymphatic deficiency and depression of cellmediated immunity in protein-calorie malnutrition. Lancet, 2, 939-944.

Sood, G. K., Deo, M. G., and Ramalingaswami, V. (1965). Anemia in experimental protein deficiency in the Rhesus monkey with special reference to iron metabolism. Blood, 26, 421-432.

Trowell, H. C., Davies, J. N. P., and Dean, R. F. A. (1954). Kwashiorkor. Edward Arnold, London. 